\title{
Fatal Herpes Simplex Virus Hepatitis in a Patient with Esophageal Cancer under Radiochemotherapy
}

\author{
Birgit Grimm ${ }^{a}$ Barbara Padberg ${ }^{b}$ Thomas Ruhstaller ${ }^{d}$ Felix Fleisch ${ }^{c}$ Roger von Moos ${ }^{a}$ \\ ${ }^{a}$ Abteilung Onkologie/Hämatologie, Departement Innere Medizin, \\ ${ }^{b}$ Departement Institute, Pathologie und Rechtsmedizin, \\ c Infektiologie, Departement Innere Medizin, Kantonsspital Graubünden, Chur, \\ ${ }^{d}$ Abteilung Onkologie/Hämatologie, Departement Innere Medizin, Kantonsspital St. Gallen, Switzerland
}

\section{Key Words}

Esophageal cancer - Herpes simplex virus .

Fulminant hepatitis

\section{Summary}

Background: Herpes simplex virus (HSV) infections are frequent. However, HSV hepatitis is rare and may lead to a life-threatening condition. Case Report: A 68-year-old patient with a locally advanced and inoperable esophageal carcinoma was treated with induction chemotherapy and combined chemoradiation. After a total of 9 weeks of treatment, he developed fulminant liver failure of unknown origin and died a few days later. Surprisingly, the post mortem examination revealed an HSV infection of the esophagus and an HSV-associated necrotisizing hepatitis. Conclusion: In this immunocompromised patient, we postulate an HSV-associated esophagitis that led to viremia and fulminant hepatitis. Especially in immunocompromised hosts, HSV hepatitis should be considered in the differential diagnosis in patients with anicteric hepatitis and marked elevation of transaminases. A liver biopsy is the quickest and most definitive diagnostic tool to diagnose HSV hepatitis. If this is not possible because of severe coagulopathy, polymerase chain reaction for HSV DNA should be performed. Awaiting diagnosis, a prompt empirical treatment with acyclovir has to be discussed in case of a characteristic biochemical profile.

\author{
Schlüsselwörter \\ Ösophaguskarzinom · Herpes-simplex-Virus . \\ Fulminante Hepatitis
}

\section{Zusammenfassung}

Hintergrund: Herpes-simplex-Virus (HSV)-Infektionen sind häufig. Sehr selten kommt es hingegen zu einer HSV-induzierten Hepatitis, die unbehandelt in der Regel tödlich verläuft. Fallbeschreibung: Ein 68-jähriger Patient mit einem lokal fortgeschrittenen und inoperablen Ösophaguskarzinom stand unter kombinierter Radiochemotherapie nach Induktionschemotherapie. Nach insgesamt 9 Behandlungswochen verstarb er an einem fulminanten Leberversagen unklarer Ätiologie. Post mortem fand sich überraschenderweise eine schwergradige HSV-Infektion des Ösophagus sowie eine HSV-assoziierte nekrotisierende Hepatitis. Schlussfolgerung: Bei diesem immunkompromittierten Patienten postulieren wir eine HSVassoziierte Ösophagitis, die zu einer Virämie und einer fulminanten Hepatitis geführt hat. Insbesondere bei immunkompromittierten Patienten sollte eine HSV-Hepatitis differentialdiagnostisch in Betracht gezogen werden, wenn eine anikterische Hepatitis mit stark erhöhten Serumtransaminasewerten vorliegt. Eine Leberbiopsie liefert den schnellsten Nachweis einer HSV-Hepatitis. Falls eine Leberbiopsie wegen einer schweren Koagulopathie nicht möglich ist, sollte ein DNA-Nachweis im Blut mittels Polymerase-Kettenreaktion-Technik versucht werden. Noch vor Erhalt des Resultates ist bei Vorliegen des typischen biochemischen Profils eine baldige empirische Behandlung mit Aciclovir zu erwägen.

\begin{tabular}{ll}
\hline KARGER & $\oplus$ 2008 S. Karger GmbH, Freiburg \\
Fax +497614520714 & Accessible online at: \\
$\begin{array}{l}\text { Information@Karger.de } \\
\text { www.karger.com }\end{array}$ & www.karger.com/onk
\end{tabular}




\section{Introduction}

Herpes simplex virus (HSV) is one of the most common causes of viral infection. The two main subtypes, HSV-1 and HSV-2, are known for their ability to cause a variety of illnesses, including mucocutaneous infections, infections of the central nervous system and an occasional infection of visceral organs [1]. HSV esophagitis may result from direct extension of oro-pharyngeal HSV infection into the esophagus or may occur by reactivation and spread of HSV along the vagus nerve to the esophageal mucosa. Host factors clearly influence the rates of infection and reactivation. Immunocompromised patients have both more frequent and more severe infections and reactivations.

\section{Case Report}

A 68-year-old man was diagnosed with an adenocarcinoma of the distal esophagus. Staging was done by endoscopy, endoscopic ultrasound and computed tomography (CT) scan and revealed stage uT3 uN1 cM0. Because of the extensive mediastinal lymphadenopathy, the patient was assessed to be inoperable. He was registered in a multicenter phase II clinical trial for advanced inoperable esophageal cancer and received 2 cycles of induction chemotherapy with docetaxel $75 \mathrm{mg} / \mathrm{m}^{2}$ and cisplatin $75 \mathrm{mg} / \mathrm{m}^{2}$ every 3 weeks. Restaging CT showed a regression of the tumor and the lymph node metastases. On day 43 the planned definitive chemoradiation was initiated: According to the protocol, the chemoradiation consisted of $59.4 \mathrm{~Gy}$ in 33 dose fractions of $1.8 \mathrm{~Gy}$ with concomitant weekly docetaxel of $15 \mathrm{mg} / \mathrm{m}^{2}$ and cisplatin of $25 \mathrm{mg} / \mathrm{m}^{2}$.

At 4 weeks after start of chemoradiotherapy the patient rapidly developed weakness, fatigue and loss of appetite without pain or dysphagia. $\mathrm{He}$ was admitted to the hospital with a decreased performance status, a temperature of $37.9^{\circ} \mathrm{C}$ and mild hepatomegaly. Laboratory analysis revealed an anicteric hepatitis with pronounced elevation of serum aminotransferases (aspartate aminotransferase (AST) $9226 \mathrm{U} / 1$ (9-45 U/1), alanine aminotransferase (ALT) $5355 \mathrm{U} / 1$ (8-63 U/1)) and lactate dehydrogenase (LDH >12,000 U/1 (240-480 U/1)), but normal bilirubin. Furthermore, it showed pancytopenia (leukocytes $0.8 \times 10^{9} / 1$, hemoglobin $112 \mathrm{~g} / \mathrm{l}$, thrombocytes $15 \times 10^{9} / 1$ ), a severe renal insufficiency with a creatinine clearance of $12 \mathrm{ml} / \mathrm{min}$ and a coagulopathy. The results of serological tests for hepatitis $\mathrm{B}$ and $\mathrm{C}$ virus were negative.

The patient died of acute failure of the liver and the kidney within 2 days, despite full supportive care.

\section{Macroscopic, Microscopic and Immunohistochemical Findings}

The autopsy revealed massive necrosis of the liver (organ $1730 \mathrm{~g}$ ); the left lobe was more severely affected than the right one (fig. 1). Light microscopy showed confluent and bridging necrosis without evidence of regeneration. A number of hepatocytes were multinucleated and exhibited a homogeneous pale chromatin, indicative of an HSV infection. Immunohistochemistry revealed nuclear and cytoplasmic positivity of the hepatocytes for HSV (fig. 2; antigen: HSV I and II; species: rabbit; dilution: prediluted; source: Cell Marque, Hot Springs, AR, USA). The squamous epithelium, adjacent to the necrotic adenocarcinoma of the lower esophagus (diameter $4 \mathrm{~cm}$; tumor stage: ypT3 ypN1 ypM0; tumor regression grade 3 (range 1-5) according to Mandard et al. [2]) showed ballooning degeneration and multinucleated keratinocytes with homogeneous pale chromatin, consistent with an HSV infection (fig. 3).

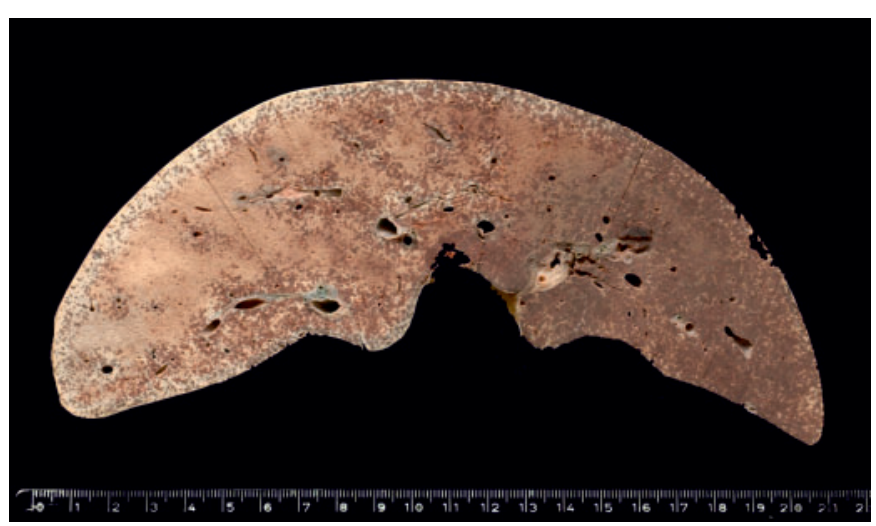

Fig. 1. Macroscopy of the liver: Massive necrosis in fatal herpetic hepatitis that progressed to liver failure. The dark zones represent massive necrosis with adjacent congested liver. The left lobe is more severely affected than the right one.

Fig. 2. Microscopy of the liver (immunoperoxidase staining directed against HSV I and II, $\times 200$ ): Necrotic and intact zones and hepatocytes with nuclear and cytoplasmic positivity for HSV.

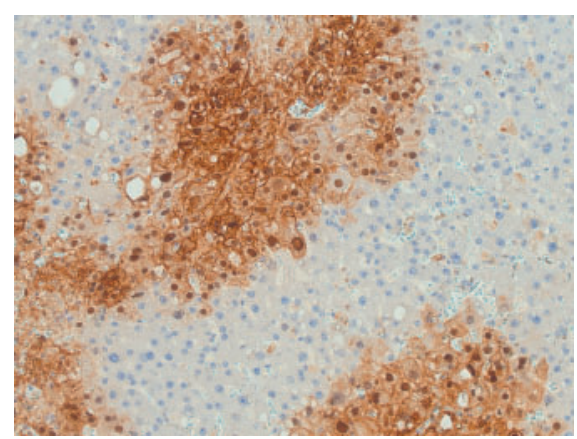

Fig. 3. Microscopy of the esophagus (hematoxylin/eosin, $\times 400$ ): Squamous epithelium with ballooning degeneration and multinucleated keratinocytes with homogeneous pale chromatin.

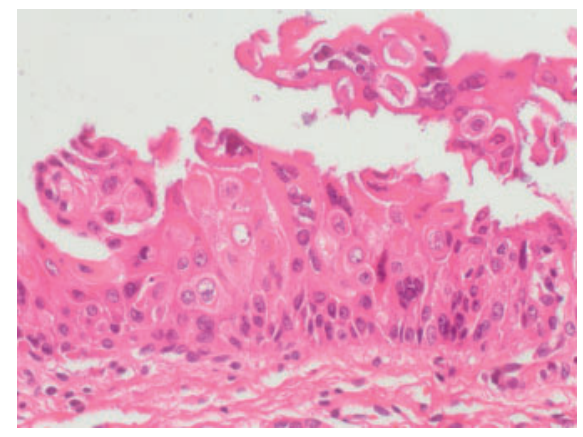

\section{Discussion}

Our patient presented with normal bilirubin and very high levels of transaminases and LDH. This characteristic pattern of liver function abnormalities can be found in approximately $90 \%$ of cases with fulminant herpes simplex hepatitis and is described as 'anicteric hepatitis'. Most of the case studies have demonstrated marked elevations of transaminases with AST $>$ ALT (up to 1000-fold). Leukopenia is also a common finding in HSV hepatitis [3-7]. In our case, the leukopenia and the thrombopenia are likely due to myelosuppression caused by the chemotherapy with docetaxel and cisplatin. Moreover, both substances accumulated in view of the severe hepatic and renal insufficiency and possibly aggravated the myelosuppression. 
In immunocompetent patients, infection by HSV can cause a mild, self-limited hepatitis. Acute hepatitis with severe liver failure is a rare manifestation of HSV infection and is usually fatal. Most of these patients have an underlying condition associated with impaired host defense. This includes organ transplantation, cytostatic therapy, prolonged treatment with corticosteroids, malignancy or disorders of the skin integrity such as burns $[6,8]$. Impaired cell-mediated immunity is thought to be responsible for HSV dissemination, although the specific mechanism is unknown [6]. Therefore, HSV hepatitis should be suspected in immunocompromised hosts with anicteric hepatitis and marked elevation of transaminases, fever and leukopenia. Mucocutaneous lesions are not necessarily part of the diagnosis, as over $40 \%$ of patients will not have identifiable oral or genital lesions or a prior history of HSV infection $[3,6,7]$.

Physicians need to be aware of the clinical abnormalities. If direct hepatotoxicity by drugs, hepatitis viruses or sepsis can be excluded, confirmatory testing for HSV should be performed. As viremia is an important factor in the pathogenesis of disseminated HSV infections in immunocompromised patients, detection of HSV viremia should be tried. This can be done with a simple blood culture method by observing cytopathic effects and confirmation by indirect fluorescent staining with monoclonal antibody to HSV [8]. Polymerase chain reaction (PCR) has emerged as a rapid and sensitive diagnostic tool for diagnosis of HSV disease by detection of HSV DNA. Routinely, it is used on viral culture, cerebrospinal fluid and biopsy specimens. Reports could show PCR detection of HSV in the plasma and peripheral blood mononuclear cells [9]. Furthermore, real-time PCR is in development [10,11].

Biopsy including immunohistochemical staining is the gold standard test in this situation [7,12]. The histology is characterized by areas of cellular necrosis with little inflammation and hepatocytes with either eosinophilic inclusion bodies or the more characteristic pattern of homogeneous pale chromatin [4-6]. However, as in our case, liver biopsy is frequently not possible because of severe coagulopathy. In individual cases, transjugular liver biopsy with appropriate plasma support can be considered [13].

In view of the high mortality and the fact that HSV hepatitis is one of the few causes of fulminant hepatic failure for which potentially effective therapy is available, HSV hepatitis has to be considered early in any case of unexplained fulminant hepatitis. If there are no obvious risk factors for other forms of hepatitis, we suggest to perform a liver biopsy or PCR for HSV in the peripheral blood prior to an empirical therapy with acyclovir. Only a rapid start of a specific therapy can improve the serious prognosis of this illness [3, 5, 7, 12,14].

\section{References}

1 Corey L: Herpes simplex virus; in Mandell GL, Bennett JE, Dolin R (eds): Mandell, Douglas, and Bennett's principles and practice of infectious diseases. Amsterdam, Elsevier, 2005, pp 1762-1780.

2 Mandard AM, Dalibard F, Mandard JC, Marnay J, Henry-Amar M, Petiot JF, Roussel A, Jacob JH Segol P, Samama G: Pathologic assessment of tumor regression after preoperative chemoradiotherapy of esophageal carcinoma. Clinicopathologic correlations. Cancer 1994;73:2680-2686.

3 Farr RW, Short S, Weissman D: Fulminant hepatitis during herpes simplex virus infection in apparently immunocompetent adults: report of two cases and review of the literature. Clin Infect Dis 1997;24: 1191-1194.

4 Fahy RJ, Crouser E, Pacht E: Herpes simplex type 2 causing fulminant hepatic failure. South Med J 2000;93:1212-1216.
5 Peters DJ, Greene WH, Ruggiero F, McGarrity T: Herpes simplex-induced fulminant hepatitis in adults: a call for empiric therapy. Dig Dis Sci 2000; 45:2399-2404.

6 Kaufmann B, Gandhi SA, Loui E, Rizzi R, Illei P: Herpes simplex virus hepatitis: Case report and review. Clin Infect Dis 1997;24:334-338.

7 Norvell JP, Blei AT, Jovanovic BD, Levitsky J: Herpes simplex virus hepatitis: an analysis of the published literature and institutional cases. Liver Transpl 2007;13:1428-1434.

8 Stanberry LR, Floyd-Reising SA, Conelly BL, Alter SJ, Gilchrist MJR, Rubio C, Myers MG: Herpes simplex viremia: report of eight pediatric cases and review of the literature. Clin Infect Dis 1994;18:401-407.

9 Diamond C, Mohan K, Hobson A, Frenkel L, Corey L: Viremia in neonatal herpes simplex virus infections. Pediat Infect Dis 1999;18:487-489.
10 Kessler HH, Mühlbauer G, Rinner B, Stelzi E, Berger A, Dörr H-W, Santner B, Marth E, Rabenau $\mathrm{H}$ : Detection of herpes simplex virus DNA by realtime PCR. J Clin Microbiol 2000;38:2638-2642.

11 Burrows J, Nitsche A, Bayly B, Walker E, Higgins G, Kok T: Detection and subtyping of herpes simplex virus in clinical samples by LightCycler PCR, enzyme immunoassay and cell culture. BMC Microbiol 2002;2:12.

12 Duckro AN, Sha BE, Jakate S, Hayden MK, Simon DM, Saltzberg SN, Arai S, Kessler HA Herpes simplex virus hepatitis: expanding the spectrum of disease. Transpl Infect Dis 2006;8:171-176.

13 Carreras E, Granena A, Navasa M, et al.: Transvenous liver biopsy in BMT. Bone Marrow Transplant 1993;11:21-26.

14 Tomita T, Garcia F, Mowry M: Herpes simplex hepatitis before and after acyclovir treatment. Arch Pathol Lab Med 1992;116:173-177. 